\title{
Hypoxia regulates the expression of tissue factor pathway signaling elements in a rat glioma model
}

\author{
ROBSON Q. MONTEIRO ${ }^{1}$, LUIZE G. LIMA ${ }^{1,2}$, \\ NATHÁLIA P. GONÇALVES ${ }^{1}$, MAYARA R. ARRUDA DE SOUZA ${ }^{1}$, ANA C. LEAL ${ }^{1}$, \\ MARCOS A. ALMEIDA DEMASI ${ }^{3}$, MARI C. SOGAYAR ${ }^{3}$ and TATIANA C. CARNEIRO-LOBO ${ }^{1}$ \\ ${ }^{1}$ Institute of Medical Biochemistry Leopoldo de Meis, Federal University of Rio de Janeiro, Rio de Janeiro, RJ 21941-902; \\ ${ }^{2}$ Bone Marrow Transplantation Center, National Institute of Cancer, Rio de Janeiro, RJ 20230-130; \\ ${ }^{3}$ Cell and Molecular Therapy Center (NUCEL-NETCEM), Internal Medicine Department, \\ School of Medicine, University of São Paulo, São Paulo, SP 05360-120, Brazil
}

Received May 29, 2015; Accepted April 22, 2016

DOI: $10.3892 / \mathrm{ol} .2016 .4593$

\begin{abstract}
Hypoxia and necrosis are fundamental features of glioma, and their emergence is critical for the rapid biological progression of this fatal tumor. The presence of vaso-occlusive thrombus is higher in grade IV tumors [glioblastoma multiforme (GBM)] compared with lower grade tumors, suggesting that the procoagulant properties of the tumor contribute to its aggressive behavior, as well as the establishment of tumor hypoxia and necrosis. Tissue factor (TF), the primary cellular initiator of coagulation, is overexpressed in GBMs and likely favors a thrombotic microenvironment. Phosphatase and tensin homolog (PTEN) loss and hypoxia are two common alterations observed in glioma that may be responsible for $\mathrm{TF}$ upregulation. In the present study, ST1 and P7 rat glioma lines, with different levels of aggressiveness, were comparatively analyzed with the aim of identifying differences in procoagulant mechanisms. The results indicated that $\mathrm{P} 7$ cells display potent procoagulant activity compared with ST1 cells. Flow cytometric analysis showed less pronounced levels of TF in ST1 cells compared with P7 cells. Notably, P7 cells supported factor X (FX) activation via factor VIIa, whereas no significant FXa generation was observed in ST1 cells. Furthermore, the exposure of phosphatidylserine on the surface of P7 and ST1 cells was investigated. The results supported the assembly of prothrombinase complexes, accounting for the production of thrombin. Furthermore, reverse transcription-quantitative polymerase chain reaction showed that $\mathrm{CoCl}_{2}$ (known to
\end{abstract}

Correspondence to: Dr Tatiana Correa Carneiro-Lobo, Institute of Medical Biochemistry Leopoldo de Meis, Federal University of Rio De Janeiro, 550 Pedro Calmon Avenue, Rio De Janeiro, RJ 21941-902, Brazil

E-mail: tatty.lobo@gmail.com

Key words: blood coagulation, glioma, hypoxia, microvesicles, protease-activated receptor, tissue factor, vascular endothelial growth factor induce a hypoxic-like stress) led to an upregulation of TF levels in P7 and ST1 cells. Therefore, increased TF expression in P7 cells was accompanied by increased TF procoagulant activity. In addition, hypoxia increased the shedding of procoagulant TF-bearing microvesicles in both cell lines. Finally, hypoxic stress induced by treatment with $\mathrm{CoCl}_{2}$ upregulated the expression of the PAR1 receptor in both P7 and ST1 cells. In addition to PAR1, P7, but not ST1 cells, expressed higher levels of PAR2 under hypoxic stress. Thus, modulating these molecular interactions may provide additional insights for the development of more efficient therapeutic strategies against aggressive glioma.

\section{Introduction}

Tissue factor (TF), the primary initiator of the coagulation cascade, is a $47-\mathrm{kDa}$ cell-associated transmembrane protein that acts as a high-affinity receptor for factor VIIa (FVIIa). Formation of the TF/FVIIa complex (extrinsic tenase complex) on cellular surfaces triggers the generation of active coagulation proteases, followed by deposition of activated platelets and fibrin (1). TF is constitutively expressed in specific cell types and has been shown to be upregulated in a number of pathological processes $(2,3)$.

A strong correlation between TF expression and malignancy grade has been reported for several tumor types, and may result in vascular occlusion and hypoxia, therefore influencing various aspects of tumor progression, including angiogenesis, metastasis and other cellular responses (4-8). Increased TF expression has been also associated with cancer-associated thrombosis, a highly relevant systemic response $(8,9)$. In fact, several studies suggest that circulating extracellular vesicles containing TF may be important in a patient's prothrombotic state $(10,11)$.

The majority of the pro-tumoral responses induced by TF are associated with the functions of activated clotting factors [FVIIa, factor Xa (FXa) and thrombin] as well as other proteases, such as matrix metalloproteinase-1 (MMP1), in cleaving and activating $\mathrm{G}$ protein-coupled protease-activated receptors (PARs) $(7,9,12)$. Activation of PAR1 by thrombin or MMP1 triggers a number of tumor cell responses, while the TF/FVIIa 
binary complex predominantly functions through activation of PAR2. In fact, it is proposed that PAR1 and PAR2 induce several redundant responses in tumor cells $(7,13)$.

Glioblastoma multiforme (GBM), the most common type of adult brain tumor, infiltrates the normal brain area, rendering complete surgical resection impossible. The disease has a poor median survival time of 15 months after diagnosis, despite the application of aggressive multimodality treatments following surgery, such as radiation and chemotherapy (14). The aggressiveness of GBM has been correlated with severe hypoxia, which generates large areas of necrosis and an extensive, hyperpermeable vasculature (15). Hypoxia activation is a hallmark of growing tumors that occurs as a result of inadequate oxygen supply. Increased angiogenesis serves to restore the influx of nutrients and oxygen to the tumor environment (16). It has been proposed that the TF signaling pathway has a relevant role in GBM progression $(17,18)$. Therefore, oncogenic signaling pathways, such as the expression of epidermal growth factor receptor (EGFR) and its mutant, EGFRvIII, as well as inactivation of the tumor suppressor phosphatase and tensin homolog (PTEN), correlate with the elevated expression of TF in GBM cell lines and patient samples (19-22).

To determine whether hypoxia can modulate the hypercoagulative activity of glioma cells, as well as TF signaling-associated elements, such as PAR receptors, the present study examined two cell lines derived from C6 rat glioma cells that differently respond to glucocorticoid treatment. Non-tumorigenic ST1 cells undergo a dramatic tumoral-to-normal phenotypic reversion, characterized by growth inhibition in monolayer cultures (with a blockage at the G0/G1 cell cycle phase), loss of the ability to form colonies in semi-solid medium, loss of ability to induce tumor formation in nude mice, and dramatic morphological changes. By contrast, P7 cells are highly aggressive and unaffected by glucocorticoid treatment $(23,24)$.

The results of the present study show that hypoxia upregulates TF expression, as well as PAR1 and PAR2 expression, in GBM cell lines. In addition, hypoxic stress increases the shedding of procoagulant TF-bearing microvesicles (MVs) by tumor cells. Together, the results provide a better understanding of the processes involved in the deregulation of the coagulation system in GBM, which appears to be critical for glioma progression. Thus, modulating these molecular interactions may offer additional insights for the development of more efficient therapeutic strategies against aggressive glioma.

\section{Materials and methods}

Cell culture. ST1 and P7 rat glioma cell lines were originally established by Armelin et al $(23,24)$ from rat C6 glial cells (American Type Culture Collection, Rockville, MD, USA) by subjecting cultures to successive passages of serum-free medium. Both cell lines were grown at $37^{\circ} \mathrm{C}$ in a humidified, $5 \% \mathrm{CO}_{2}$ atmosphere in culture flasks by subconfluent passages in Dulbecco's modified Eagle medium/F12 (DMEM/F12; Gibco; Thermo Fisher Scientific, Inc., Waltham, MA, USA) supplemented with $2 \mathrm{~g} / \mathrm{l} \mathrm{HEPES}, 60 \mathrm{mg} / \mathrm{l}$ streptomycin and $1.2 \mathrm{~g} / 1$ sodium bicarbonate. For hypoxia experiments, cells were cultured in fresh medium containing 250 or $500 \mu \mathrm{M}$ $\mathrm{CoCl}_{2}$ (Sigma-Aldrich, St. Louis, MO, USA) for 4, 12 or $24 \mathrm{~h}$.
MV purification from cell culture supernatants. Cell culture supernatants were consecutively centrifuged at $800 \mathrm{x} \mathrm{g}$ for $10 \mathrm{~min}$ and at $20,000 \mathrm{x} \mathrm{g}$ for $20 \mathrm{~min}$, both at $4^{\circ} \mathrm{C}$. The final pellet was then washed once in phosphate-buffered saline (PBS), resuspended in PBS and stored at $-80^{\circ} \mathrm{C}$ until utilization. MVs were quantified by counting in a FACSCalibur Flow Cytometer (BD Biosciences).

In vitro activation of plasma coagulation. The procoagulant activity of cells and MVs was measured by performing a clotting assay employing platelet-poor plasma (PPP) from rats. Cells or MVs $(50 \mu \mathrm{l})$ resuspended in PBS at different concentrations were added to $50 \mu \mathrm{M}$ PPP containing $3.8 \%$ sodium citrate $\left(1: 9 \mathrm{v} / \mathrm{v}\right.$ dilution). After $1 \mathrm{~min}$ incubation at $37^{\circ} \mathrm{C}$, $100 \mu \mathrm{M}$ of $6.25 \mathrm{mM} \mathrm{CaCl}_{2}$ was added and the clotting times were recorded using a KC-4 coagulometer (Sigma Amelung, Lemgo, Germany).

Reverse transcription-quantitative polymerase chain reaction $(R T-q P C R)$. RNA was isolated from P7 or ST1 cells $\left(2.5 \times 10^{5}\right)$ using the TRIzol reagent (Invitrogen; Thermo Fisher Scientific, Inc.) and reverse transcribed into cDNA using SuperScript III Reverse Transcriptase (Invitrogen; Thermo Fisher Scientific, Inc.), according to the manufacturer's instructions. mRNA expression levels were quantified by qPCR on a 7300 Real-Time PCR System (Applied Biosystems; Thermo Fisher Scientific, Inc.) using SYBR Green Master Mix. Sequence-specific primers were designed using Primer Express software (version 3; Applied Biosystems; Thermo Fisher Scientific, Inc.). The qPCR primers were as follows: Forward, 5'-CAGAGCAGGACAGAAAAGGAAGAA-3 and reverse, 5'-GCGTCAGCCTCCTCGTCTAT-3' for rat TF; forward, 5'-AACTGCTAGCCTCTGGATTTGATG and reverse, 5'-AAAGACAAGGCAACCGATACTTC-3' for rat PTEN; forward 5'-TGTGCGGGCTGCTGCAATGAT-3' and reverse 5'-TGTGCTGGCTTTGGTGAGGTTTGA-3' for rat vascular endothelial growth factor (VEGF); forward, 5'-CCT GTGCGGTCCTTTGCT-3' and reverse, 5'-CATCCTCTC AGATTCTGGCTGTCT-3' for rat PAR1; forward, 5'-AGA GGTATTGGGTCATGTG-3' and reverse, 5'-GCAGGAATG AACATGGTCTG-3' for rat PAR2; forward, 5'-GCTGAA GATTTGGAAAGGTGT-3' and reverse, 5'-GCTGAAGAT TTGGAAAGGTGT-3' for the control, rat HPRT. Gene expression levels were analyzed using the software provided by the PCR system's manufacturer. The $\Delta \Delta \mathrm{Cq}$ method (25) was used to quantify the amplification-fold difference between $\mathrm{P} 7$ and ST1 cells with the $\mathrm{Cq}$ value of the target genes being adjusted to the housekeeping gene (HPRT). Assays were performed in triplicate with variability $<0.5 \mathrm{Ct}$.

Flow cytometric analysis. For surface phosphatidylserine (PS) detection, tumor cells $\left(100 \mu \mathrm{l}\right.$ at $1 \times 10^{6}$ cells $\left./ \mathrm{ml}\right)$ were incubated for $15 \mathrm{~min}$ at room temperature with fluorescein isothiocyanate-conjugated Annexin V (Santa Cruz Biotechnology Inc., Santa Cruz, CA, USA) diluted to 1:100 in binding buffer (10 mM HEPES, $150 \mathrm{mM} \mathrm{NaCl}, 2.5 \mathrm{mM} \mathrm{CaCl}_{2}$ ). Tumor cells (100 $\mu \mathrm{l}$ at $1 \times 10^{6}$ cells $/ \mathrm{ml}$ ) were then resuspended in $100 \mu \mathrm{l} \mathrm{PBS}$ containing $1 \% \mathrm{BSA}$ and incubated for $30 \mathrm{~min}$ at $4{ }^{\circ} \mathrm{C}$ with a goat polyclonal antibody against rat $\mathrm{TF}(200 \mu \mathrm{g} / \mathrm{ml}$; cat no. 4501; Sekisui Diagnostics, LLC, Lexington, MA, USA). After 
washing with $1 \%$ BSA in PBS to remove unbound antibody, cells were incubated with a fluorescein-conjugated anti-goat IgG (1:200, sc-2777, Santa Cruz Biotechnology Inc.). Cells were then washed again with $1 \%$ BSA in PBS and analyzed using a FACSCalibur Flow Cytometer (BD Biosciences, San Jose, CA, USA). In all cases, data were analyzed using CellQuest Pro software version 5.1.1 (BD Biosciences). Data were expressed as global geometric mean fluorescence intensity $(\triangle \mathrm{MFI})$, which represents the difference between the MFI of stained and the MFI of unstained samples compared with the P7 cell line

FX activation via hydrolysis of chromogenic substrates. Activation of FX by the extrinsic tenase complex (TF/FVII)awas performed in HEPES-BSA buffer [50 mM HEPES, $100 \mathrm{mM}$ $\mathrm{NaCl}, 5 \mathrm{mM} \mathrm{CaCl}, 1 \mathrm{mg} / \mathrm{ml} \mathrm{BSA} \mathrm{(pH} \mathrm{7.5)],} \mathrm{as} \mathrm{follows:} \mathrm{FVIIa}$ (final concentration, $1 \mathrm{nM})$ was incubated with cells $\left(5 \times 10^{5} / \mathrm{ml}\right)$ or MVs $\left(5 \times 10^{3} / \mathrm{ml}\right)$ for $10 \mathrm{~min}$ at $37^{\circ} \mathrm{C}$ in HEPES-BSA buffer. The reaction was initiated by the addition of FX (final concentration, $100 \mathrm{nM}$ ) and aliquots of $25 \mu \mathrm{l}$ were removed at different times into microplate wells containing $25 \mu 1$ Tris-EDTA buffer [50 mM Tris- $\mathrm{HCl}, 150 \mathrm{mM} \mathrm{NaCl}, 20 \mathrm{mM}$ EDTA, $1 \mathrm{mg} / \mathrm{ml}$ polyethyleneglycol-6000 (pH 7.5)]. Following the addition of $50 \mu \mathrm{l}$ of $200 \mu \mathrm{M}$ S-2765 (chromogenic substrate; Diapharma, West Chester, $\mathrm{OH}$, USA) prepared in Tris-EDTA buffer at $37^{\circ} \mathrm{C}$ for $30 \mathrm{~min}$, absorbance was recorded at $405 \mathrm{~nm}$ in 6-sec intervals using a ThermoMax Microplate Reader (Molecular Devices, LLC, Menlo Park CA, USA). Velocities [mean optical density (mOD)/min] obtained in the first minute of the reaction were used to calculate the amount of FXa formed, as compared with a standard curve using known enzyme concentrations. In order to ensure that FX activation was strictly dependent on extrinsic tenase complex assembly, negative controls were performed in the absence of FVIIa and showed no significant formation of FXa.

Prothrombin activation via hydrolysis of chromogenic substrates. Activation of prothrombin by the prothrombinase complex [FXa/factor Va (FVa)] was performed in HEPES-BSA buffer using a discontinuous assay. FXa (final concentration, $10 \mathrm{pM}$ ) was incubated with FVa (final concentration, $1 \mathrm{nM}$; Haematological Technologies Inc., Essex Junction, VT, USA) in the presence of cells $\left(5 \times 10^{5} / \mathrm{ml}\right)$ for $2 \mathrm{~min}$ at $37^{\circ} \mathrm{C}$. The reaction was initiated by addition of prothrombin (final concentration, $500 \mathrm{nM}$; Haematological Technologies Inc.) and aliquots of $10 \mu \mathrm{l}$ were removed every $1 \mathrm{~min}$ into microplate wells containing $40 \mu \mathrm{l}$ Tris-EDTA buffer. Following the addition of $50 \mu \mathrm{l}$ of $200 \mu \mathrm{M} \mathrm{S}-2238$ (Diapharma) prepared in Tris-EDTA buffer at $37^{\circ} \mathrm{C}$ for $20 \mathrm{~min}$, absorbance was recorded at $405 \mathrm{~nm}$ in 6-sec intervals using a ThermoMax Microplate Reader (Molecular Devices, LLC). Velocities $(\mathrm{mOD} / \mathrm{min})$ obtained in the first minute of the reaction were used to calculate the amount of thrombin formed, as compared with a standard curve using known enzyme concentrations. In order to ensure that prothrombin activation was strictly dependent on prothrombinase complex assembly, negative controls were performed in the absence of $\mathrm{FXa} / \mathrm{FVa}$ and showed no significant formation of thrombin.

Statistical analysis. One-way analysis of variance followed by Bonferroni's multiple comparison test or unpaired t-test were performed using GraphPad Prism software (version 5;
GraphPad Software, Inc., San Diego, CA, USA). Data are presented as the mean \pm standard deviation of three independent experiments. The differences were considered to be statistically significant at $\mathrm{P}<0.05$.

\section{Results}

Differential expression of TF in rat GBM cell lines. Previous studies have demonstrated that TF expression is correlated with the histological grade of malignancies in glioma (26,27). Using a one-stage clotting assay, the present study observed that P7 cells display potent procoagulant activity when compared with ST1 cells (Fig. 1A). As TF significantly contributes to the activation of plasma coagulation, the levels of TF expression were also determined in both GBM cell lines. Analysis by RT-qPCR demonstrated that $\mathrm{P} 7$ cells express significantly higher levels of TF mRNA than ST1 cells (Fig. 1B). In vitro studies previously suggested that upregulation of TF in high-grade glioma is associated with loss of tumor suppressor PTEN $(19,21,22)$. Consistent with this hypothesis, Fig. 1B shows that the levels of PTEN mRNA are inversely correlated with TF expression in both P7 and ST1 cells. In addition, flow cytometric analysis showed less pronounced levels of TF antigen on the surface of ST1 cells compared with P7 cells. The ST1 cell line presented an 3.5 -fold increase in $\triangle \mathrm{MFI}$ (Fig. 1C). Finally, TF activity was analyzed in the P7 and ST1 cells. Notably, P7 cells supported the assembly of extrinsic tenase complex with significant FX activation by FVIIa compared with the control cells, whereas no significant FXa generation was observed for ST1 cells under the same conditions (Fig. 1D).

Our previous studies have demonstrated that viable tumor cells may expose the anionic phospholipid PS on the outer leaflet of the cell membrane $(28,29)$. This exposure is required for the assembly of membrane-dependent procoagulant complexes. Therefore, the present study investigated whether differential PS exposure could contribute to the variable procoagulant properties of P7 and ST1 cells. Flow cytometric analysis employing Annexin V indicated that P7 cells presented an $\sim 1$-7-fold increase in global geometric $\triangle \mathrm{MFI}$ compared with ST1 cells (Fig. 2A). Furthermore, the assembly of the prothrombinase complex (FVa/FXa/prothrombin), a process that is critically dependent on the presence of PS-rich anionic membranes, was investigated. Consistently, P7 cells supported prothrombin activation more efficiently than ST1 cells (Fig. 2B). Controls performed in the absence of FXa and FVa showed negligible thrombin formation.

The results indicate that the higher procoagulant activity of P7 cells relative to ST1 appears to be particularly associated with their expression of the primary clotting initiator, TF. However, distinct patterns of PS exposure may also augment these discrepancies.

Hypoxic stress upregulates TF expression and TF-FVIIa activity. In GBM, intratumoral activation of the coagulation system is directly associated with vascular occlusions, triggering interlinked processes, such as hypoxia, necrosis and angiogenesis $(17,30)$. It is well established that hypoxia induces the expression of angiogenic regulators, such as VEGF, in GBM cells, promoting the formation of new vessels and driving rapid tumor growth. Fig. 3A reveals upregulation of VEGF mRNA 
A

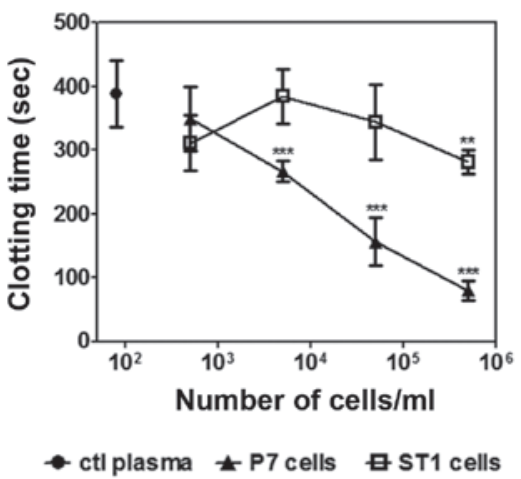

C

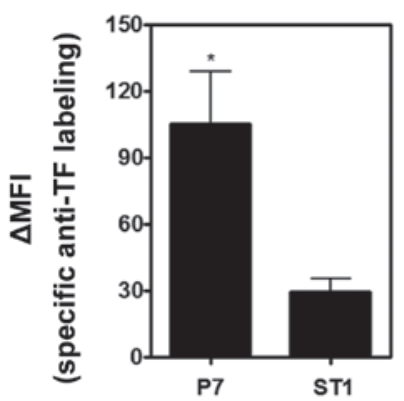

B
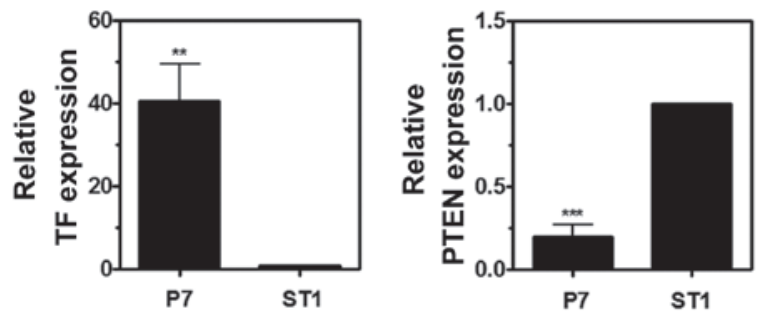

D

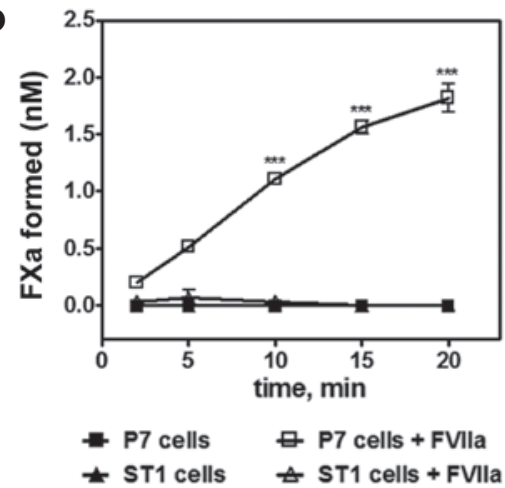

Figure 1. Analysis of the procoagulant properties of P7 and ST1 glioma cells. (A) Clotting time of P7 and ST1 cells. The black circle represents coagulation time of rat platelet-poor plasma in the absence of tumor cells. ${ }^{* *} \mathrm{P}<0.01$ or ${ }^{* * *} \mathrm{P}<0.001$ vs. ctl plasma, one-way analysis of variance (ANOVA) followed by Bonferroni's post-hoc test. (B) Reverse transcription-quantitative polymerase chain reaction analysis of TF and PTEN gene expression in P7 and ST1 cells. ${ }^{* *} \mathrm{P}=0.0048$ and ${ }^{* * * *} \mathrm{P}=0.00041$, respectively, unpaired t-test. (C) Flow cytometric analysis of TF expression in P7 and ST1 cells. Relative specific labelling of cells by an anti-rat TF polyclonal antibody $\triangle$ MFI represents the geometric MFI difference between stained and unstained samples. " $\mathrm{P}=0.0361$, unpaired t-test. (D) Assembly of the extrinsic tenase complex on ST1 and P7 cells. Kinetics for the activation of FX $(100 \mathrm{nM})$ in the presence of FVIIa $(1 \mathrm{nM})$ in P7 or ST1 cells (5x10 $/ \mathrm{ml})$. Controls were performed in the absence of FVIIa. ${ }^{* * *} \mathrm{P}<0.001$ vs. control, one-way ANOVA followed by Bonferroni's post-hoc test. Data are presented as the mean \pm standard deviation of three independent experiments. ctl, control; MFI, mean fluorescence intensity; TF, tissue factor; PTEN, phosphatase and tensin homolog; FXa, factor Xa.

A

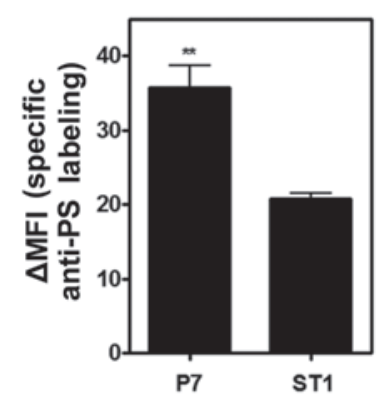

B

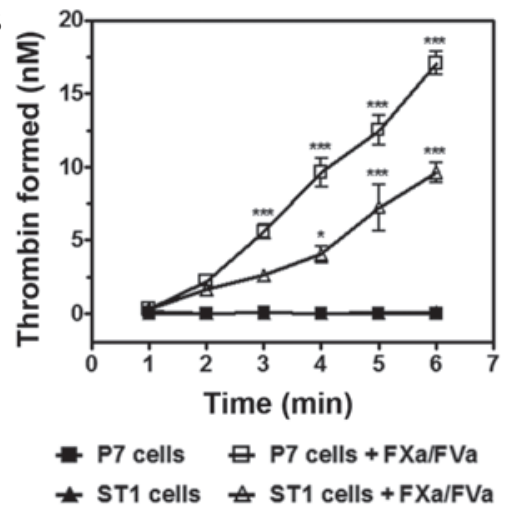

Figure 2. PS exposure and assembly of the prothrombinase complex on P7 and ST1 glioma cells. (A) Detection of PS exposure by flow cytometry. Relative specific labeling of P7 and ST1 cells by fluorescein isothiocyanate-conjugated Annexin V, with $\triangle$ MFI representing the geometric MFI difference between stained and unstained samples. ${ }^{* *} \mathrm{P}=0.0079$, unpaired t-test. (B) Kinetics for the activation of prothrombin (500 nM) by FXa $(10 \mathrm{pM})$ and FVa (1 nM) in the presence of P7 or ST1 cells $\left(5 \times 10^{5} / \mathrm{ml}\right)$. Controls were performed in the absence of FXa and FVa. ${ }^{*} \mathrm{P}<0.05$ or ${ }^{* * *} \mathrm{P}<0.001$ vs. control, one-way analysis of variance followed by Bonferroni's post-hoc test. Data are presented as the mean \pm standard deviation of three independent experiments. MFI, mean fluorescence intensity; PS, phosphatidylserine; FXa/Va, factor Xa/Va.

expression in $\mathrm{P} 7$ and $\mathrm{ST} 1$ cells upon exposure to $\mathrm{CoCl}_{2}(250$ or $500 \mu \mathrm{M} \mathrm{CoCl}_{2}$ for $4 \mathrm{~h}$ ), which is known to induce hypoxic-like stress. Next, the present study investigated whether treatment with $\mathrm{CoCl}_{2}$ could upregulate TF expression in cancer cells. P7 and ST1 cells were exposed to $\mathrm{CoCl}_{2}$, and TF mRNA and protein levels were determined by RT-qPCR and flow cytometry, respectively. In comparison to normoxic conditions, the cultivation of P7 cells in $500 \mu \mathrm{M} \mathrm{CoCl}_{2}$ for $4 \mathrm{~h}$ significantly increased TF mRNA levels; however, this change was not observed in ST1 cells (Fig. 3B). Accordingly, flow cytometry showed a time-dependent upregulation of TF levels in P7 cells upon treatment with $\mathrm{CoCl} 2(250$ or $500 \mu \mathrm{M})$, with a peak at $12 \mathrm{~h}$ (data 
A

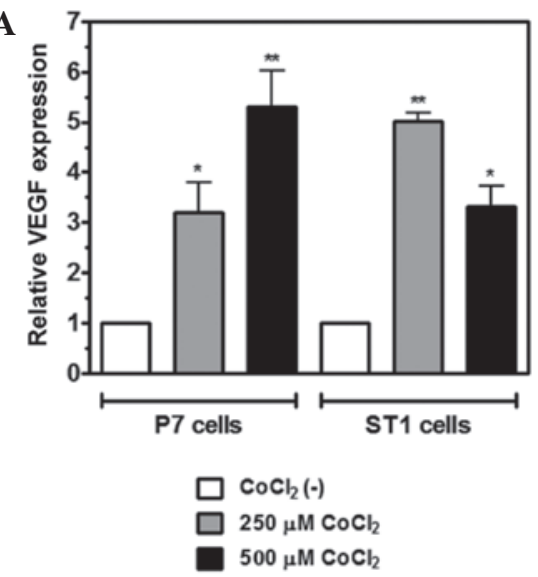

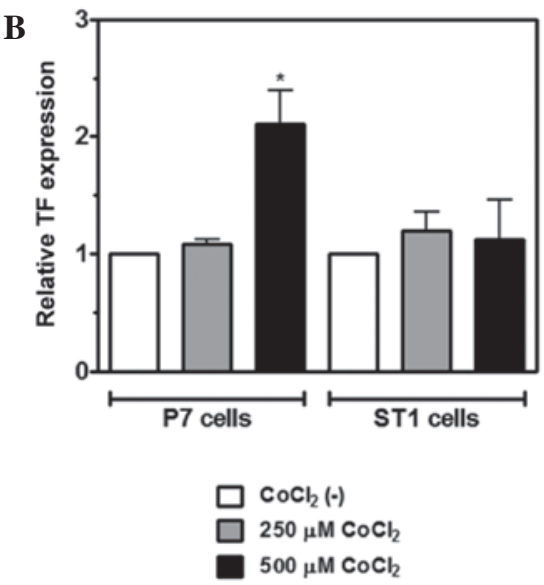

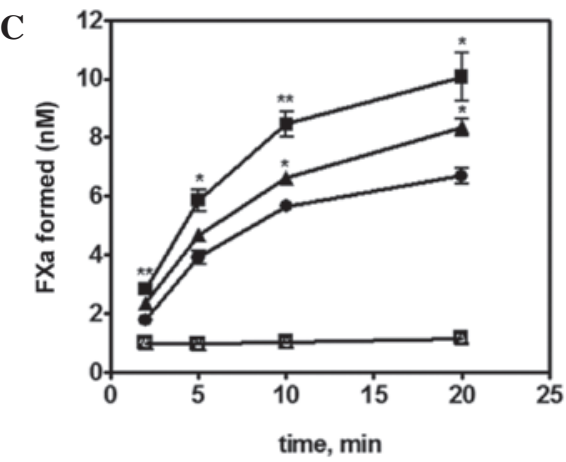

$\square \begin{aligned} & 250 \mu \mathrm{M} \mathrm{CoCl} \\ & 500 \mu \mathrm{M} \mathrm{CoCl}\end{aligned}$

Figure 3. Hypoxia regulates the expression and activity of TF. Reverse transcription-quantitative polymerase chain reaction analysis indicating relative (A) VEGF or (B) TF mRNA expression in P7 and ST1 cells stimulated with 250 or $500 \mu \mathrm{M} \mathrm{CoCl}_{2}$ for $4 \mathrm{~h}$ (hypoxic conditions) or without CoCl $\mathrm{C}_{2}$ [normoxic conditions, $\left.\mathrm{CoCl}_{2}(-)\right]$. (C) Assembly of the extrinsic tenase complex. Kinetics for the activation of FX $(100 \mathrm{nM})$ in the presence of FVIIa $(1 \mathrm{nM})$ in P7 or ST1 cells $\left(5 \times 10^{5} / \mathrm{ml}\right)$ stimulated with 250 or $500 \mu \mathrm{M} \mathrm{CoCl}_{2}$ for $12 \mathrm{~h}$ (hypoxic conditions) were compared with cells cultured under normoxia. Controls were performed in the absence of FVIIa. " $\mathrm{P}<0.05$ or ${ }^{* *} \mathrm{P}<0.01$ vs. normoxic conditions, one-way analysis of variance followed by Bonferroni's post-hoc test. Data are presented as the mean \pm standard deviation of three independent experiments. VEGF, vascular endothelial growth factor; TF, tissue factor; FXa/VIIa, factor Xa/VIIa.

A

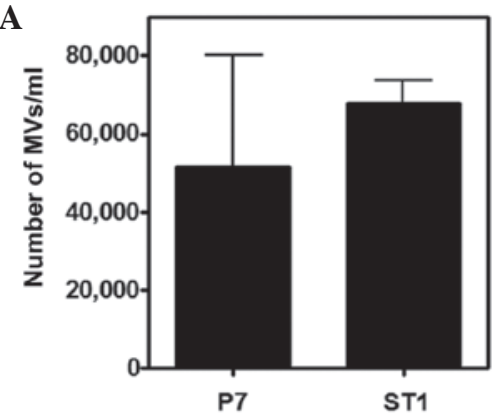

C

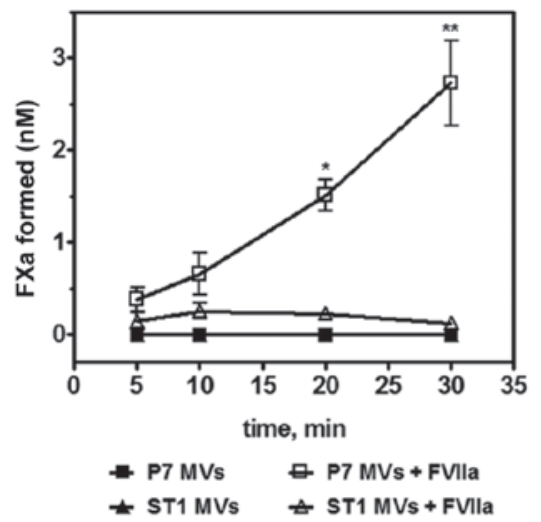

B

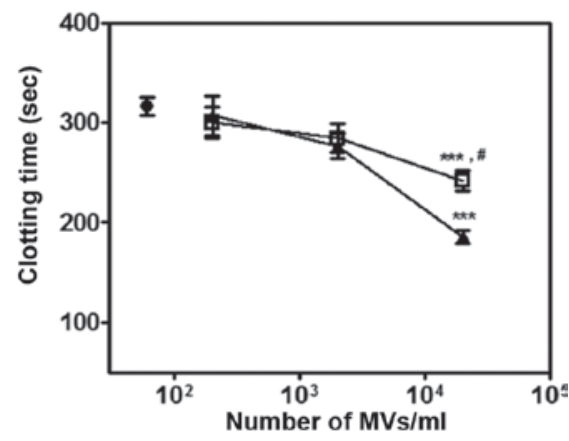

D

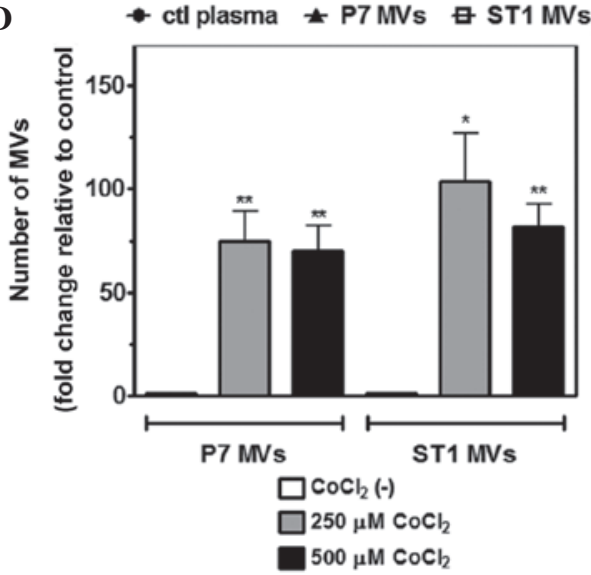

Figure 4. Shedding of MVs by P7 and ST1 cells. (A) MVs were isolated from P7 and ST1 cell 24-h culture supernatants, resuspended in equal volumes of phosphate-buffered saline (PBS) and quantified by flow cytometry. (B) Procoagulant activity of P7 and ST1 MVs. Black circle represents coagulation time of rat platelet-poor plasma in the absence of MVs. ${ }^{* * *} \mathrm{P}<0.001$ vs. control plasma; ${ }^{*} \mathrm{P}=0.0004$ vs. ST1 MVs. (C) Assembly of the extrinsic tenase complex on ST1 and P7 MVs. Kinetics for the activation of FX $(100 \mathrm{nM})$ in the presence of FVIIa $(1 \mathrm{nM})$ in P7 or ST1 MVs $\left(5 \times 10^{3} / \mathrm{ml}\right)$. Controls were performed in the absence of FVIIa. "P<0.05 or "* P<0.01 vs. control. (D) Hypoxia increases MV release from P7 and ST1 cells. MVs were isolated from 24-h culture supernatants of P7 and ST1 cells stimulated with 250 or $500 \mu \mathrm{M} \mathrm{CoCl}_{2}$ (hypoxic conditions), resuspended in equal volumes of PBS and quantified by flow cytometry. Controls were performed in the absence of $\mathrm{CoCl}_{2}$ (normoxic conditions). ${ }^{\mathrm{P}}<0.05$ or ${ }^{* *} \mathrm{P}<0.01$ vs. normoxic conditions. Statistical analysis for (B-D) was performed by one-way analysis of variance followed by Bonferroni's post-hoc test. Data are presented as the mean \pm standard deviation of three independent experiments. MVs, microvesicles; FXa/IIa. factor Xa/IIa.

not shown). To evaluate whether hypoxia-induced upregulation of TF expression is accompanied by an increase in TF procoagulant activity, an FXa generation assay by the extrinsic tenase complex was performed. P7 and ST1 cells were cultured under normoxic and hypoxic conditions ( 250 or $500 \mu \mathrm{M} \mathrm{CoCl}_{2}$ ) for $12 \mathrm{~h}$. The FX activation supported by P7 cells was enhanced at 
A

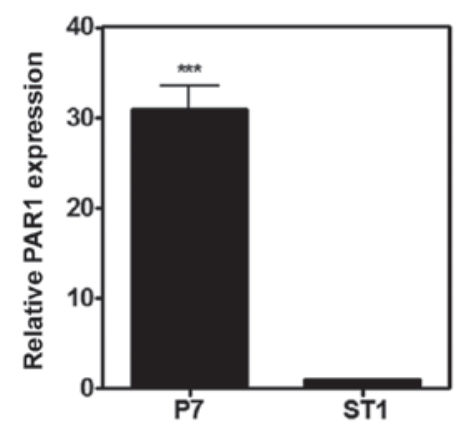

B

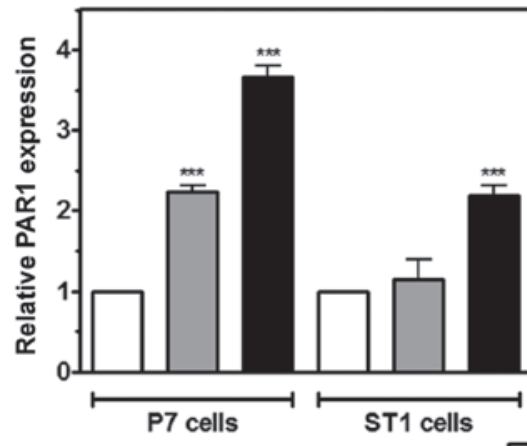

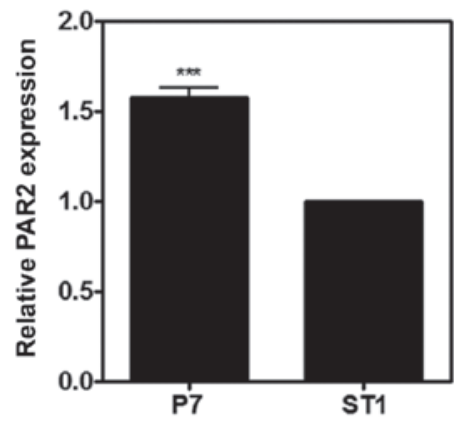

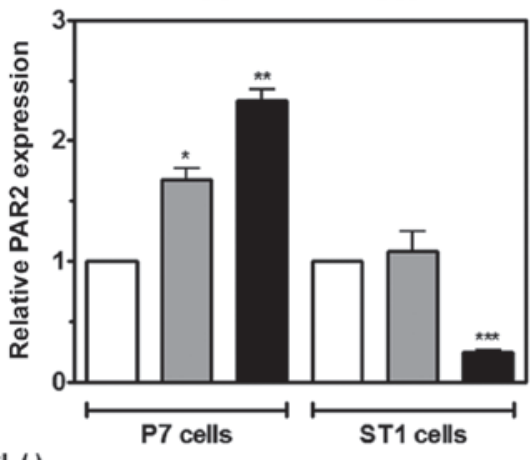

Figure 5. Hypoxia increases PAR1 and PAR2 expression in P7 and ST1 cells. (A) Reverse transcription-quantitative polymerase chain reaction (RT-qPCR) analysis of PAR 1 and PAR 2 mRNA expression in P7 and ST1 cells. ${ }^{* * *} \mathrm{P}<0.001$, unpaired t-test. (B) RT-qPCR analysis of PAR1 and PAR2 mRNA expression

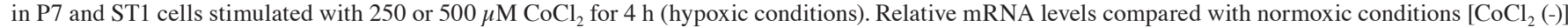
are shown. ${ }^{*} \mathrm{P}<0.05,{ }^{* *} \mathrm{P}<0.01$ or ${ }^{* * *} \mathrm{P}<0.001$ vs. normoxic conditions, one-way analysis of variance followed by Bonferroni's post-hoc test. Data are presented as the mean \pm standard deviation of three independent experiments. PAR1/2, protease-activated receptor 1/2.

both $\mathrm{CoCl}_{2}$ concentrations (Fig. 3C). However, no increase in TF activity was observed for stimulated ST1 cells. The results of the present study indicate that hypoxia upregulates functionally active TF antigen on the surface of P7 cells, but not on ST1 cells.

Shedding of procoagulant MVs by P7 and ST1 cells. TF has been shown to circulate in the blood as a component of cell-derived MVs. Increased secretion of TF-positive MVs has been observed in several types of cancer and has been associated with the activation of the hemostatic system $(7,31)$. Therefore, the present study analyzed the spontaneous shedding of MVs by P7 and ST1 cell lines in vitro. Differential centrifugation was performed to isolate MVs from the supernatants of P7 and ST1 cell cultures. Flow cytometric analysis revealed a similar rate of MV production for both cell lines (Fig. 4A). Using a one-stage clotting assay, it was observed that MVs derived from P7 and ST1 cells shortened the coagulation time of rat plasma at similar concentration ranges (Fig. 4B). TF activity was also investigated in these MVs. Comparably to their parental cells, $\mathrm{P} 7 \mathrm{MVs}$ supported FX activation by the extrinsic tenase complex (TF/FVIIa), while ST1 MVs showed no TF activity (Fig. 4C). No significant FXa generation was observed in the absence of FVIIa.

Hypoxiahas been shown to markedly increase TF-containing extracellular vesicle secretion in glioma cells (32). Therefore, the present study investigated whether hypoxia increases the secretion of MVs into the conditioned media of P7 and ST1 cell cultures. The incubation of both cell lines with 250 or $500 \mu \mathrm{M}$ $\mathrm{CoCl}_{2}$ for $24 \mathrm{~h}$ promoted a significant enhancement in $\mathrm{MV}$ secretion when compared with normoxic conditions (Fig. 4D).
Taken together, these results demonstrate that P7 cells and TF-bearing MVs exhibit higher TF activity than ST1 cells, a process that is significantly enhanced upon exposure to hypoxia.

Hypoxic induction of PAR expression in P7 and ST1 cells. In addition to TF, hypoxic stress has been shown to modulate PAR1 expression in tumor cell lines (32,33). Furthermore, our recent study observed increased PAR1 and PAR2 staining around necrotic areas in samples from patients with GBM (22). In this context, the present study analyzed the effect of $\mathrm{CoCl}_{2}$ treatment on PAR expression in rat glioma cells. RT-qPCR showed that PAR1 and PAR2 mRNA are expressed in P7 and ST1 cells, and that P7 cells express higher mRNA levels of both receptors when compared with ST1 cells (Fig. 5A). Following treatment with 250 or $500 \mu \mathrm{M} \mathrm{CoCl}_{2}$ for $4 \mathrm{~h}$, mRNA expression of PAR1 was significantly upregulated in both cell lines, whereas an increase in PAR2 expression was observed only in P7 cells (Fig. 5B). Conversely, ST1 cells exhibited significantly reduced levels of PAR2 mRNA when treated with $500 \mu \mathrm{M} \mathrm{CoCl}_{2}$.

\section{Discussion}

A dramatic shift in biological behavior occurs following the transition from astrocytoma to GBM. These changes include accelerated growth and rapid progression to mortality. The mechanisms responsible for this abrupt onset of rapid growth are still being defined but are likely associated with the development of necrosis and intense angiogenesis, which are two 
defining features of GBM histology and powerful predictors of poor prognosis $(15,34)$. Almost all GBM specimens show microscopic intravascular thrombosis within tissue specimens and this event has been documented as an additional distinguishing pathological feature of GBM compared with lower grade astrocytoma (35). Furthermore, necrosis and subsequent hypoxia-induced angiogenesis may be initiated or propagated by intravascular thrombosis.

In the present study, it was demonstrated that hypoxia, a key event in GBM, induces increased expression of the potent procoagulant TF in GBM cells and promotes TF/FVIIa activity. This phenomenon markedly differs between the GBM cell lines P7, a highly aggressive, glucocorticoid-resistant cell line, and ST1, a non-tumorigenic, glucocorticoid-sensitive cell line. Under normoxia, P7 exhibits $\sim 3.5$-fold higher expression of TF as compared with ST1, with strong significant inverse correlation of PTEN expression. This reflects the ability of these cell lines to promote plasma clotting and FX activation. Notably, hypoxic stress promoted by treatment with $\mathrm{CoCl}_{2}$ significantly enhanced TF expression and activity in the P7 cell line.

In addition to TF, the present study also demonstrated the presence of the procoagulant phospholipid PS on the outer leaflet of P7 and ST1 cells, which supports FX activation through the assembly of the prothrombinase complex, leading to rapid thrombin generation. Both cell lines exhibit PS exposure, with the lipid exposure more prominent in the aggressive cell line, P7. Notably, Blanco et al recently demonstrated that increased PS exposure occurs in vivo in a xenograft mice model (36). Therefore, PS is proposed as a target for the delivery of nanovesicles in the treatment and imaging of GBM.

Previous studies have demonstrated that hypoxia elevates the release of MVs by tumor cells $(31,37)$. Herein, it was demonstrated that hypoxic stress significantly increases the production of MVs from P7 or ST1 cells. The increased incidence of venous thrombosis throughout the course of GBM has been well documented (38). In fact, the elevated levels of circulating MVs in cancer patients has been correlated with thrombosis in a number of cancer types $(9,11,30)$. However, it has previously been demonstrated that elevated levels of TF-positive MVs do not correlate with thrombosis occurrence in patients with GBM (39). Additionally, intratumoral expression of TF has not been correlated with thrombosis in patients with GBM (40). However, increased MV production upon the induction of hypoxic stress has been associated with TF transfer from tumor to endothelial cells in a GBM model. This process triggers a proangiogenic cascade dependent on PAR2 signaling in endothelial cells that in turn results in an increase in PAR2 expression upon hypoxia (32). In addition, TF-containing MVs may promote TF transfer between tumor cell lines with different aggressive behaviors, thus, modulating their procoagulant properties (41).

Several lines of evidence suggest that PAR1 has a significant role in GBM progression. For example, Zhang et al observed elevated PAR1 expression in GBM and identified a correlation with patient survival (42). In addition, our previous study demonstrated that PAR1 expression was significantly enhanced in patients with GBM compared with those exhibiting lower grade gliomas, and PAR1 expression was positively correlated with VEGF expression (22). PAR1 expression has also been documented in a rat glioma model (43). Herein, it was demonstrated that hypoxic stress upregulates PAR1 expression in P7 and ST1 cell lines. Notably, the aggressive cell line, P7, exhibited a significantly higher degree of PAR1 expression under normoxia than the ST1 cell line. Therefore, PAR1 may contribute to GBM progression and may have an important role in hypoxia-driven events.

In addition to PAR1, PAR2 has been associated with GBM progression. In vitro assays demonstrate that PAR2 activation mediates several pro-tumoral responses in GBM cell lines (20-24,26-46). Therefore, blocking the TF/PAR2 signaling axis has been identified as a feasible target for the treatment of GBM $(45,47,48)$. As observed with PAR1, the P7 cell line expressed higher levels of PAR2 than ST1 under normoxia in the present study. Notably, hypoxic stress significantly enhanced PAR2 expression in P7 but not ST1 cells. Thus, PAR2 signaling may be involved in hypoxia-driven progression of patients with GBM, resulting in a more aggressive pattern.

In conclusion, the present study demonstrates that hypoxia enhances TF expression and MVs generation in rat GBM cell lines. In addition, hypoxic stress upregulates PAR1 and PAR2 expression, a process that was highly evident in a glucocorticoid resistant cell line. The results indicate that therapies targeted against TF-PAR signaling axis may be relevant in GBM, particularly those presenting with more aggressive behavior.

\section{References}

1. Williams JC and Mackman N: Tissue factor in health and disease. Front Biosci 1: 358-372, 2012.

2. Østerud B and Bjørklid E: Sources of tissue factor. Semin Thromb Hemost 32: 11-23, 2006.

3. Francischetti IM, Seydel KB and Monteiro RQ: Blood coagulation, inflammation, and malaria. Microcirculation 15: 81-107, 2008.

4. Brat DJ and Van Meir EG: Vaso-occlusive and prothrombotic mechanisms associated with tumor hypoxia, necrosis, and accelerated growth in glioblastoma. Lab Invest 84: 397-405, 2004.

5. Rak J, Milsom C, Magnus N and Yu J: Tissue factor in tumour progression. Best Pract Res Clin Haematol 22: 71-83, 2009.

6. Kasthuri RS, Taubman MB and Mackman N: Role of tissue factor in cancer. J Clin Oncol 27: 4834-4838, 2009.

7. Ruf W, Disse J, Carneiro-Lobo TC, Yokota N and Schaffner F: Tissue factor and cell signalling in cancer progression and thrombosis. J Thromb Haemost 9 (Suppl 1): S306-S315, 2011

8. van den Berg YW, Osanto S, Reitsma PH and Versteeg $\mathrm{HH}$ : The relationship between tissue factor and cancer progression: Insights from bench and bedside. Blood 119: 924-932, 2012.

9. Lima LG and Monteiro RQ: Activation of blood coagulation in cancer: Implications for tumour progression. Biosci Rep 33: e00064, 2013.

10. Lima LG, Oliveira AS, Campos LC, Bonamino M, Chammas R, Werneck C, Vicente CP, Barcinski MA, Petersen LC and Monteiro RQ: Malignant transformation in melanocytes is associated with increased production of procoagulant microvesicles. Thromb Haemost 106: 712-723, 2011.

11. Zhou L, Qi XL, Xu MX, Mao Y, Liu ML and Song HM: Microparticles: New light shed on the understanding of venous thromboembolism. Acta Pharmacol Sin 35: 1103-1110, 2014.

12. Boire A, Covic L, Agarwal A, Jacques S, Sherifi S and Kuliopulos A: PAR1 is a matrix metalloprotease-1 receptor that promotes invasion and tumorigenesis of breast cancer cells. Cell 120: 303-313, 2005.

13. Albrektsen T, Sørensen BB, Hjort $\varnothing$ GM, Fleckner J, Rao LV and Petersen LC: Transcriptional program induced by factor VIIa-tissue factor, PAR1 and PAR2 in MDA-MB-231 cells. J Thromb Haemost 5: 1588-1597, 2007.

14. Wen PY and Kerasi S: Malignant gliomas in adults. N Engl J Med 359: 492-507, 2008. 
15. Evans SM, Judy KD, Dunphy I, Jenkins WT, Nelson PT, Lustig RA, Jenkins K, Magarelli DP, Hahn SM, Collins RA, et al: Hypoxia is important in the biology and aggression of human glial brain tumors. Clin Cancer Res 10: 8177-8184, 2004.

16. Brown JM and Wilson WR: Exploiting tumour hypoxia in cancer treatment. Nat Rev Cancer 4: 437-447, 2004.

17. Anand $\mathrm{M}$ and Brat DJ: Oncogenic regulation of tissue factor and thrombosis in cancer. Thromb Res 129 (Suppl 1): S46-S49, 2012.

18. Magnus N, D'Asti E, Meehan B, Garnier D and Rak J: Oncogenes and the coagulation system-forces that modulate dormant and aggressive states in cancer. Thromb Res 133 (Suppl 2): S1-S9, 2014.

19. Rong Y, Post DE, Pieper RO, Durden DL, Van Meir EG and Brat DJ: PTEN and hypoxia regulate tissue factor expression and plasma coagulation by glioblastoma. Cancer Res 65: 1406-1413, 2005.

20. Magnus N, Garnier D and Rak J: Oncogenic epidermal growth factor receptor up-regulates multiple elements of the tissue factor signaling pathway in human glioma cells. Blood 116: 815-818, 2010.

21. D'Asti E, Fang Y and Rak J: Brain neoplasms and coagulation-lessons from heterogeneity. Rambam Maimonides Med J 5: e0030, 2014.

22. Carneiro-Lobo TC, Lima MT, Mariano-Oliveira A, Dutra-Oliveira A, Oba-Shinjo SM, Marie SK, Sogayar MC and Monteiro RQ: Expression of tissue factor signaling pathway elements correlates with the production of vascular endothelia growyh factor and interleukin-8 in human astrocytoma patients. Oncol Rep 31: 679-686, 2014.

23. Armelin MC and Armelin HÀ: Glucocorticoid hormone modulation of both cell surface and cytoskeleton related to growth control of rat glioma cells. J Cell Biol 97: 459-465, 1983.

24. Armelin MC, Stocco RC and Armelin HA: Control of rat C6 glioma cell proliferation: Uncoupling of the inhibitory effects of hydrocortisone hormone in suspension and monolayer cultures. J Cell Biol 97: 455-458, 1983.

25. Livak KJ and Schmittgen TD: Analysis of relative gene expression data using real-time quantitative PCR and the $2-\Delta \Delta \mathrm{Ct}$ Methods 25: 402-408, 2001.

26. Hamada K, Kuratsu J, Saitoh Y, Takeshima H, Nishi T and Ushio Y: Expression of tissue factor correlates with grade of malignancy in human glioma. Cancer 77: 1877-1883, 1996.

27. Guan M, Jin J, Su B, Liu WW and Lu Y: Tissue factor expression and angiogenesis in human glioma. Clin Biochem 35: 321-325, 2002.

28. Fernandes RS, Kirszberg C, Rumjanek VM and Monteiro RQ: On the molecular mechanisms for the highly procoagulant pattern of C6 glioma cells. J Thromb Haemost 4: 1546-1552, 2006.

29. Kirszberg C, Lima LG, Da Silva de Oliveira A, Pickering W, Gray E, Barrowcliffe TW, Rumjanek VM and Monteiro RQ: Simultaneous tissue factor expression and phosphatidylserine exposure account for the highly procoagulant pattern of melanoma cell lines. Melanoma Res 19: 301-308, 2009.

30. Brat DJ, Castellano-Sanchez AA, Hunter SB, Pecot M, Cohen C, Hammond EH, Devi SN, Kaur B and Van Meir EG: Pseudopalisades in glioblastoma are hypoxic, express extracellular matrix proteases and are formed by an actively migrating cell population. Cancer Res 64: 920-927, 2004.

31. Rautou PE and Mackman N: Microvesicles as risk markers for venous thrombosis. Expert Rev Hematol 6: 91-101, 2013.

32. Svensson KJ, Kucharzewska P, Christianson HC, Sköld S, Löfstedt T, Johansson MC, Mörgelin M, Bengzon J, Ruf W and Belting M: Hypoxia triggers a proangiogenic pathway involving cancer cell microvesicles and PAR-2-mediated heparin-binding EGF signaling in endothelial cells. Proc Natl Acad Sci USA 108 13147-13152, 2011.
33. Naldini A, Filippi I, Ardinghi C, Silini A, Giavazzi R and Carraro F: Identification of a functional role for the protease-activated receptor-1 in hypoxic breast cancer cells. Eur J Cancer 45: 454-460, 2009.

34. Hammoud MA, Sawaya R, Shi W, Thall PF and Leeds NE: Prognostic significance of preoperative MRI scans in glioblastoma multiforme. J Neurooncol 27: 65-73, 1996.

35. Tehrani M, Friedman TM, Olson JJ and Brat DJ: Intravascular thrombosis in central nervous system malignancies: A potential role in astrocytoma progression to glioblastoma. Brain Pathol 18: 164-171, 2008

36. Blanco VM, Chu Z, Vallabhapurapu SD, Sulaiman MK, Kendler A, Rixe O, Warnick RE, Franco RS and Qi X: Phosphatidylserine-selective targeting and anticancer effects of SapC-DOPS nanovesicles on brain tumors. Oncotarget 5: 7105-7118, 2014

37. Wang T, Gilkes DM, Takano N, Xiang L, Luo W, Bishop CJ, Chaturvedi P, Green JJ and Semenza GL: Hypoxia-inducible factors and $\mathrm{RAB} 22 \mathrm{~A}$ mediate formation of microvesicles that stimulate breast cancer invasion and metastasis. Proc Natl Acad Sci USA 111: E3234-E3242, 2014.

38. Marras LC, Geerts WH and Perry JR: The risk of venous thromboembolism is increased throughout the course of malignant glioma: An evidence-based review. Cancer 89: 640-664, 2000.

39. Thaler J, Ay C, Mackman N, Bertina RM, Kaider A, Marosi C, Key NS, Barcel DA, Scheithauer W, Kornek G, et al: Microparticle-associated tissue factor activity, venous thromboembolism and mortality in pancreatic, gastric, colorectal and brain cancer patients. J Thromb Haemost 10: 1363-1370, 2012.

40. Thaler J, Preusser M, Ay C, Kaider A, Marosi C, Zielinski C, Pabinger I and Hainfellner JA: Intratumoral tissue factor expression and risk of venous thromboembolism in brain tumor patients. Thromb Res 131: 162-165, 2013.

41. Lima LG, Leal AC, Vargas G, Porto-Carreiro I and Monteiro RQ: Intercellular transfer of tissue factor via the uptake of tumor-derived microvesicles. Thromb Res 132: 450-456, 2013.

42. Zhang Y, Zhan H, Xu W, Yuan Z, Lu P, Zhan L and Li Q: Upregulation of matrix metalloproteinase-1 and proteinase-activated receptor-1 promotes the progression of human gliomas. Pathol Res Pract 207: 24-29, 2011.

43. Itsekson-Hayosh Z, Shavit-Stein E, Last D, Goez D, Daniels D, Bushi D, Gera O, Zibly Z, Mardor Y, Chapman J and Harnof S: Thrombin activity and thrombin receptor in rat glioblastoma model: Possible markers and targets for intervention? J Mol Neurosci 56: 644-651, 2015.

44. Dutra-Oliveira A, Monteiro RQ and Mariano-Oliveira A: Protease-activated receptor-2 (PAR2) mediates VEGF production through the ERK1/2 pathway in human glioblastoma cell lines. Biochem Biophys Res Commun 421: 221-227, 2012.

45. Harter PN, Dützmann S, Drott U, Zachskorn C, Hattingen E, Capper D, Gessler F, Senft C, Seifert V, Plate KH, et al: Anti-tissue factor (TF9-10H10) treatment reduces tumor cell invasiveness in a novel migratory glioma model. Neuropathology 33: 515-525, 2013.

46. Luo R, Wang X, Dong Y, Wang L and Tian C: Activation of protease-activated receptor 2 reduces glioblastoma cell apoptosis. J Biomed Sci 21: 25, 2014.

47. Carneiro-Lobo TC, Konig S, Machado DE, Nasciutti LE, Forni MF, Francischetti IM, Sogayar MC and Monteiro RQ: Ixolaris, a tissue factor inhibitor, blocks primary tumor growth and angiogenesis in a glioblastoma model. J Thromb Haemost 7: 1855-1864, 2009.

48. Carneiro-Lobo TC, Schaffner F, Disse J, Ostergaard H, Francischetti IM, Monteiro RQ and Ruf W: The tick-derived inhibitor Ixolaris prevents tissue factor signaling on tumor cells. J Thromb Haemost 10: 1849-1858, 2012. 